\title{
Flaxseed Soluble Dietary Fibre Enhances Lactic Acid Bacterial Survival and Growth in Kefir and Possesses High Antioxidant Capacity
}

\author{
Mehri HadiNezhad ${ }^{1}$, Camille Duc ${ }^{1}$, Nam Fong $\operatorname{Han}^{2} \&$ Farah Hosseinian ${ }^{1}$ \\ ${ }^{1}$ Food Science and Nutrition Program, Chemistry Department, Carleton University, Ottawa, Ontario, Canada \\ ${ }^{2}$ Natunola Health Inc., Winchester, Ontario, Canada \\ Correspondence: Farah Hosseinian, 1125 Colonel By Drive, Chemistry Department, Carleton University, Ottawa, \\ Ontario, Canada, K1S 5B6. Tel: 1-613-520-2600 x 2048; Fax: 1-613-520-3749. E-mail: \\ farah_hosseinian@carleton.ca
}

Received: June 6, 2013 Accepted: September 4, 2013 Online Published: September 17, 2013

doi: $10.5539 /$ jfr.v2n5p152

URL: http://dx.doi.org/10.5539/jfr.v2n5p152

\begin{abstract}
This study investigated the capability and efficiency of flaxseed soluble dietary fibre /mucilage to enhance bacterial survival and growth in kefir as well as the antioxidant activity of the mucilage. Crude flaxseed mucilage was extracted using a microwave method, followed by enzymatic and dialysis treatments to obtain pure mucilage. The antioxidant activities of the pure and crude mucilage were measured using different assays. Microbial analyses, $\mathrm{pH}$ and total titratable acidity (TTA) were measured in kefir samples, supplemented with probiotic bacteria (Lactobacillus acidophilus and Bifidobacterium lactis) and pure or crude flaxseed mucilage during 28 cold storage periodat $4{ }^{\circ} \mathrm{C}$. The results showed that for all kefir samples, the total bacteria counts were above 7.9 $\log \mathrm{cfu} / \mathrm{mL}$ at the end of cold storage period. However, kefir samples supplemented with pure flaxseed mucilage enhanced significantly $(\mathrm{P}<0.05)$ higher viability of bacteria $(9.5 \log \mathrm{cfu} / \mathrm{mL})$ and acidity $(0.78 \%$ TTA). An overall $\mathrm{pH}$ decline of 0.2 was observed during cold storage period. The total phenolic content (TPC) in crude mucilage was significantly $(\mathrm{P}<0.05)$ higher than pure mucilage $(10.5 \pm 0.2$ and $5.7 \pm 0.1 \mathrm{mg}$ Gallic acid equivalent /g flaxseed, respectively). The mucilage from crude flaxseed exhibited strong antioxidant activity; Oxygen Radical Absorbance Capacity (ORAC) value of $51.2 \pm 3.3 \mu \mathrm{mol}$ Trolox equivalent $/ \mathrm{g}, 53.7 \pm 2.8 \%$ discoloration for 2,2-diphenyl-1-picrylhydrazyl (DPPH), and 68.3 $\pm 9.2 \% \beta$-Carotene bleaching which was well in agreement with high TPC. This study demonstrated that flaxseed mucilage acts as a good source of prebiotic, enhancing lactic acid bacteria growth in kefir model in addition of their high antioxidant beneficiary.
\end{abstract}

Keywords: flaxseed mucilage, dairy product, bacterial growth, antioxidant activity, microwave extraction

\section{Introduction}

Flaxseed is the seed from the plant (Linum usitatissimum L.) and is consumed as food. Health benefits claims of flaxseed are related to its components such aslignans, $\alpha$-linolenic acid, and soluble dietary fibre or mucilage/gum (Bloedon \& Szapary, 2004; Hijova, Chmelarova, \& Bomba, 2011). Many studies have demonstrated that consumption of flaxseed show some health benefits such as colon cancer prevention and reducingthe risk of cardiovascular disease (Bloedon \& Szapary, 2004; Hijova et al., 2011).

There are considerable numbers of researches investigating dietary fiber from new sources to use in food industry as a source of prebiotic (Roberfroid \& Slavin, 2000; Singh \& Singh, 2010; Torres, Goncalves, Teixeira, \& Rodrigues, 2010). Non-digestible polysaccharides such as galacto-oligosaccharides, fructooligo-saccharides and cyclodextrins are known to be prebiotic substances which selectively stimulate the growth and/or activity of the gastrointestinal micro-flora (Gibson, Probert, Loo, Rastall, \& Roberfroid, 2004). The heterogenic polysaccharide, flaxseed mucilage/gum, is the soluble fiber components that constitute about 6 to $8 \%$ of the whole seed (on a dry weight basis; Cui \& Mazza, 1996). Fodje, Chang, and Leterme (2009) demonstrated that high amounts of acetate and propionate (short-chain fatty acids) resulted when flaxseed was fermented in vitro. Generally, fermentation rate was highest in soluble flaxseed gum relative to flax meal orwheat and rye bran, owing to its high solubility, thus, flaxseed mucilage could be a source of dietary fibre (Fodje et al., 2009). In addition, some oligosaccharides and polysaccharides (e.g. flaxseed mucilage) have been reported as food 
additives with anti-tumour and antioxidant properties; capturing free radicals thus preventing cancers due to oxidation of proteins, lipid or DNA (Gutiérrez et al., 2010).

Kefir is a traditional beverage from Western and Central Asia which is made through fermentation of milk using kefir grains (Simova et al., 2002). It was unknown as diet for people from Europe and America, but recently, it is increasingly getting popularity around the world. The difference between kefir and other fermented milks is the starter culture. The bacteria types reported in the kefir grains include Lactobacillus, Lactococcus, Leuconostoc and Acetobacter with the two main bacteria Streptococcus thermophilus and Lactococcus lactis consisting $53-65 \%$ of the total microflora (Miguel, Cardoso, Lago, \& Schwan, 2010; Simova et al., 2002). It also contains yeasts as Kluyveromyces, Saccharomyces, Candida and Torulopsis genus (Kök-Tas, Ekinci, \& Guzel-Seydim, 2012) that can digest lactose, reducing lactose intolerance (Hertzler \& Clancy, 2003). Many nutritional and health benefits have been claimed for kefir (Hosono et al., 1990; Vinderola, Perdigon, Duarte, Farnworth, \& Matar, 2006).

To the best of our knowledge, there is no report of employing flaxseed gum in kefir as a source of prebiotic. Therefore, the objective of the present study was to evaluate the prebiotic potential and activity of crude and pure flaxseed mucilage by measuring microbial viability, $\mathrm{pH}$ and the titratable acidity (TTA) in kefir.

\section{Materials and Methods}

\subsection{Materials}

Flaxseed used in this study was purchased from a commercial source (Bulk Barn, Ottawa, Canada). Enzymes including $\alpha$-amylase (Bacillus licheniformis, Type XII-A, saline solution $\geq 500 \mathrm{U} / \mathrm{mg}$ protein biuret) and protease (Bacillus licheniformis $\geq 2.4 \mathrm{U} / \mathrm{g}$ protein) were purchased from Sigma-Aldrich (St. Louis, Missouri, USA). The probiotics were obtained from USDA-ARS Culture Collection (National Center for Agricultural Utilization Research, Peoria, IL, USA), and they included Lactobacillus acidophilus (B-4495) and Bifidobacterium lactis (41405). The starter culture used for the kefir was kefir Type B (without production of $\left.\mathrm{CO}_{2}\right)$, (Abiasa, Saint Hyacinthe, Quebec, Canada). All the chemicals used were analytical grades.

\subsection{Methods}

\subsubsection{Extraction of Mucilage by Microwave Extraction}

A green-ecofriendly microwave technique was used to extract flaxseed mucilage. The microwave extraction of flaxseed mucilage was conducted according to the method describe by Nemes and Orsat (2011) with some modifications using a CEM STAR 2 Plus System (CEM Corporation, Matthews, NC, USA) operating at $800 \mathrm{w}$ maximum power and $2455 \mathrm{MHz}$ frequency. Whole ground flaxseed $(5 \mathrm{~g})$ was mixed with distilled water (150 $\mathrm{mL}$ ) in the quartz tube and then placed inside the microwave cavity with temperature set at $90{ }^{\circ} \mathrm{C}$ for $30 \mathrm{~min}$. Extracts were allowed to cold at room temperature and then centrifuged with a Sorvall Legend XTR centrifuge (Thermo Scientific, Ashville, NC, USA) at $2500 \mathrm{~g}$ for $20 \mathrm{~min}$; the supernatant obtained corresponds to the crude mucilage and was used for further analysis. To obtain pure mucilage, $\alpha$-amylase and protease $(10 \mu \mathrm{L}$ of each for $50 \mathrm{~mL}$ of extract) were added to the crude mucilage to remove starch and proteins. The extract was stirred overnight at $37^{\circ} \mathrm{C}$, cooled, centrifuged at $2500 \mathrm{~g}$ for $20 \mathrm{~min}$ at room temperature and supernatant was dialyzed against double distilled water for $48 \mathrm{~h}$ and water was refreshed every $6 \mathrm{~h}$ to separate polysaccharides and other materials with molecular weight cut-off of 3500 D (Spectra/Por dialysis membrane, Rancho Dominguez, CA, USA). The pure mucilage was collected and kept at freezer $\left(-20^{\circ} \mathrm{C}\right)$ for further analysis.

\subsubsection{Total Phenolic Content (TPC)}

The TPC was determined using the Folin-Ciocalteu method described by Hosseinian and Mazza (2009). Briefly, the extract $(200 \mu \mathrm{L})$ was mixed with $1.9 \mathrm{~mL}$ of 10 -fold distilled-water diluted Folin-Ciocalteu reagent, and after $5 \mathrm{~min}$ at room temperature, $1.9 \mathrm{~mL}$ of sodium carbonate solution $(60 \mathrm{~g} / \mathrm{L})$ was added. After $120 \mathrm{~min}$ of incubation in the dark place at room temperature, the blank (distilled water) and samplesabsorbanceweremeasured at $725 \mathrm{~nm}$ using the Varian Cary 50 Bio UV/Visible Spectrophotometer (Varian, Mulgrave, Australia). The absorbance was measured in triplicate and the average absorbance was used to determine the total phenolic content. Gallic acid was used as standard and the results were expressed as Gallic acid equivalent (GAE).

\subsubsection{ORAC Assay}

The ORAC assay using fluorescein as fluorescent probe was performed to measure antioxidant activity of crude and pure flaxseed mucilage as described by Agil and Hosseinian (2012). The tests were conducted at $37^{\circ} \mathrm{C}$ using a Multi-Detection Micro-plate Reader (BioTek Instruments, Ottawa, ON, Canada). The fluorescence intensity 
was measured after $60 \mathrm{~min}$ (excitation wavelength, $485 \mathrm{~nm}$; emission wavelength, $525 \mathrm{~nm}$ ) and the ORAC value was determined by comparing the net area under the curve of the extracts, crude and pure, with the equation of the Trolox standard curve. Final ORAC values were expressed as $\mu$ molTrolox equivalent per $\mathrm{g}$ of flaxseed $(\mu \mathrm{mol}$ $\mathrm{TE} / \mathrm{g})$.

\subsection{4 $\mathrm{DPPH}^{*}$ Scavenging Activity Assay}

The DPPH ${ }^{*}$ scavenging activity of flaxseed mucilage extract was measured as described by Li, Hydamaka, Lowry, and Beta (2009). Briefly, a fresh solution of $60 \mu \mathrm{M}$ DPPH was prepared in $95 \%$ ethanol solution. $200 \mu \mathrm{L}$ of the extract was mixed with $3.8 \mathrm{~mL}$ of the DPPH solution. The blank $(95 \%$ ethanol) and extracts, crude and pure, absorbance was measured at $515 \mathrm{~nm}$ for $60 \mathrm{~min}$ at $10 \mathrm{~min}$ intervals using the Varian Spectrophotometer. The antioxidant activity was calculated as \% of DPPH discolorationusing the Equation 1 below:

$$
\% \mathrm{DPPH}_{\mathrm{dis}}=\left[1-\left(\mathrm{A}_{\text {sample, } \mathrm{t}} / \mathrm{A}_{\text {control, } \mathrm{t} 0}\right)\right] \times 100
$$

Where $A_{\text {sample, }}$ is the absorbance of the sample at $515 \mathrm{~nm}$ at the different times and $\mathrm{A}_{\text {control, to }}$ the initial absorbance of the control (DPPH solution).

\subsection{5 $\beta$-Carotene Bleaching Test}

This antioxidant assay was conducted as described by AidiWannes et al. (2010). Briefly, a $0.4 \mathrm{mM} \beta$-carotene solution $(1 \mathrm{~mL})$ was made in chloroform, and $40 \mu \mathrm{L}$ of linoleic acid and $400 \mu \mathrm{L}$ of Tween 80 were added. After drying the chloroform with nitrogen, $100 \mathrm{~mL}$ of double distilled water was added. An aliquot $(3 \mathrm{~mL})$ of this solution was added to $300 \mu \mathrm{L}$ of the flaxseed mucilage extract. Samples were incubated in a water bath at $50{ }^{\circ} \mathrm{C}$ for $2 \mathrm{~h}$. The absorbance was measured against the blank (double distilled water) at $470 \mathrm{~nm}$ at 0 and $2 \mathrm{~h}$. The $\% \beta$-Carotene bleaching (which represents the antioxidant activity) was calculated using the Equation 2 below:

$$
\% \beta \text {-Carotene bleaching }=\left[\left(\mathrm{A}_{\text {sample } \mathrm{t}=2 \mathrm{~h}}-\mathrm{A}_{\text {control, } \mathrm{t}=2 \mathrm{~h}}\right) /\left(\mathrm{A}_{\text {control, } \mathrm{t}=0}-\mathrm{A}_{\text {control, } \mathrm{t}=2 \mathrm{~h}}\right)\right] \times 100
$$

Where $A_{\text {Sample } t=2 h}$ is the absorbance of the sample after $2 \mathrm{~h}$ of incubation, $A_{\text {Control } t=2 h}$ is the absorbance of the control after $2 \mathrm{~h}$ of incubation, $\mathrm{A}_{\text {Control } \mathrm{t}=0}$ is the initial absorbance of the control.

\subsubsection{Prebiotic and Probiotic Activity of Kefir}

Prebiotic activity of kefir samples were measured according to a method described by Espirito Santo et al. (2010).

\subsubsection{Probiotic Culture}

The probiotics used were Lactobacillus acidophilus (probiotic 1) and Bifidobacterium animalis subsp. lactis (probiotic 2). Probiotic culture $(100 \mu \mathrm{L})$ was added to $15 \mathrm{~mL}$ sterile test tubes containing $10 \mathrm{~mL}$ of MRS agar broth (Oxoid Ltd., Basingstoke, United Kingdom). The mix was incubated at $37^{\circ} \mathrm{C}$ for $24 \mathrm{~h}$. Then, $100 \mu \mathrm{L}$ of the mix was placed into Petri dishes containing MRS agar media. Petri dishes were incubated at $37^{\circ} \mathrm{C}$ for $24 \mathrm{~h}$. Next, a couple of colonies were placed into $10 \mathrm{~mL}$ MRS broth and incubated at $37{ }^{\circ} \mathrm{C}$ overnight. To obtain the probiotic cultures, the test tubes were centrifuged at $2500 \mathrm{~g}$ for $20 \mathrm{~min}$ at room temperature. The agar supernatant was decanted and $10 \mathrm{~mL}$ of sterile water was added to rinse the bacteria. The test tubes were centrifuged again at $2500 \mathrm{~g}$ for $20 \mathrm{~min}$ at room temperature. The water supernatant was decanted and $5 \mathrm{~mL}$ of sterile water was added. Dilutions were made using sterile milk and concentration adjusted to $6.5 \log \mathrm{cfu} / \mathrm{mL}$.

\subsubsection{Kefir Preparation}

Homogenized and pasteurized milk (3.5\%) purchased from a commercial source (Ottawa, ON, Canada) was stirred at $85{ }^{\circ} \mathrm{C}$ for $15 \mathrm{~min}$, cooled to $42{ }^{\circ} \mathrm{C}$. An aliquot was transferred into $50 \mathrm{~mL}$ sterile test-tubes, and starter culture(kefir grain, $2 \mathrm{~g} / \mathrm{L}$ of milk), the crude or pure flaxseed mucilage $(2 \mathrm{~g})$ and probiotics $(1 \mathrm{~mL})$ were added to the milk as described in Table 1. Treatments were incubated at room temperature overnight and then stored at $4{ }^{\circ} \mathrm{C}$ for 28 days. Three replications were conducted for each treatment.

\subsubsection{Microbiological Analyses}

Bacterial enumerations were performed on day 1, 7, 14, 21 and 28 in triplicate. Serial dilutions of each kefir treatment were made, and an aliquot $(10 \mu \mathrm{L})$ was plated onto MRS agar dishes using the spread plate method followed by $24 \mathrm{~h}$ incubation in an anaerobic condition at $37{ }^{\circ} \mathrm{C}$. The number of colonies was counted and the number of cells was converted into $\log \mathrm{cfu} / \mathrm{mL}$.

2.2.6.4 Total Titratable Acidity (TTA) and $\mathrm{pH}$

To determine TTA, $1 \mathrm{~mL}$ of sample was mixed with $9 \mathrm{~mL}$ of sterile water. The solution was titrated with $0.1 \mathrm{~N}$ 
$\mathrm{NaOH}$ using $0.1 \%(\mathrm{w} / \mathrm{v})$ phenolphthalein indicator. The TTA values were reported as $\%$ lactic acid equivalent. The $\mathrm{pH}$ of the kefir samples was measured using a Denver Instrument UB-5 pH meter (Denver Instrument, Bohemia, New York, USA).

\subsection{Statistical Analyses}

All experiments were conducted in triplicate and data were expressed as means \pm SD. Different kefir formulations during cold storage period were statistically compared for total microbial count, TTA, and $\mathrm{pH}$. The mucilage properties (TPC and antioxidant activities) were also compared between crude and pure mucilage. These differences were assessing using analysis of variance (ANOVA), SAS (version 9.2, SAS Institute Inc., Cary, NC, USA). Duncan's Multiple Range test was used to compare values with statistically significant differences $(\mathrm{P}<0.05)$.

Table 1. Different kefir formulations and their coding

\begin{tabular}{llll}
\hline \multirow{2}{*}{ Sample coding } & \multicolumn{3}{l}{ Ingredient (amount is expressed per 1L of milk) } \\
\cline { 2 - 4 } & Kefir grain $(\mathrm{g})$ & Flaxseed mucilage $(2 \mathrm{~g})$ & Probiotic $^{*}(1 \mathrm{~mL})$ \\
\hline $\mathrm{K}$ & 2 & - & - \\
$\mathrm{K}+1$ & 2 & - & 1 \\
$\mathrm{~K}+2$ & 2 & - & 2 \\
$\mathrm{~K}+1+2$ & 2 & - & $1 \& 2$ \\
$\mathrm{KC}$ & 2 & Crude & - \\
$\mathrm{KC}+1$ & 2 & Crude & 1 \\
$\mathrm{KC}+2$ & 2 & Crude & 2 \\
$\mathrm{KC}+1+2$ & 2 & Crude & $1 \& 2$ \\
$\mathrm{KP}$ & 2 & Pure & - \\
$\mathrm{KP}+1$ & 2 & Pure & 1 \\
$\mathrm{KP}+2$ & 2 & Pure & 2 \\
$\mathrm{KP}+1+2$ & 2 & Pure & $1 \& 2$ \\
\hline
\end{tabular}

"Probiotic 1: Lactobacillus acidophilus, Probiotic 2: Bifidobacterium lactis.

\section{Results and Discussions}

\subsection{Total Phenolic Content of Flaxseed Mucilage}

The TPC results of the crude and pure flaxseed mucilage are shown in Table 2 . There were nearly as twice TPC in crude (10.5 mg GAE/g flaxseed) as in pure flaxseed mucilage (5.7 $\mathrm{mg}$ GAE/g flaxseed). This significant difference $(\mathrm{p}<0.05)$ demonstrate that during purification of flaxseed mucilage, a marked amount of phenolic compounds are removed. Flaxseed lignans secoisolariciresinol diglycoside (SDG) and other pheonlics such as phenolic acids might have contributed to the higher TPC of crude mucilage. SDG is a diphenolic that is conjugated with the mucilage and also is water soluble. SDG and its aglycone (SECO) were the major lignans in flaxseed (7 mg/g) (Mazur et al., 1996; Thompson, Robb, Serraino, \& Cheung, 1991) that have shown biological activities such as antioxidant, and antitumor properties (MacRae \&Towers, 1984). Flaxseed also contains free phenolic acids, conjugated phenolic acids and flavonoids which can explain the higher antioxidant activity of crude mucilage. Oomah, Kenaschuck, and Mazza (1995) reported a content of 3-5 mg etherified phenolic acids per $\mathrm{g}$ flaxseed, while Kozlowska, Zadernowski, and Sosulski (1983) reported the free phenolic acids present of $0.20-0.28 \mathrm{mg} / \mathrm{g}$ defatted flaxseed flour and flavonoids present of $0.49-0.87 \mathrm{mg} / \mathrm{g}$ defatted flaxseed flour. In our study, microwave extraction technique for flaxseed mucilage resulted in higher TPC value comparing to the conventional methods which reflects the merit of this green technique as a promising method to extract plant bioactive compounds (Beejmohun et al., 2007; Chiremba, Rooney, \& Beta, 2012). 
Table 2. Total phenolic content (TPC), ORAC value, $\% \mathrm{DPPH}_{\mathrm{dis}}$, and $\% \beta$-Carotene inhibition of crude and pure flaxseed mucilage

\begin{tabular}{lllll}
\hline Flaxseed mucilage & $\begin{array}{l}\text { TPC } \\
(\mathrm{mg} \mathrm{GAE} / \mathrm{g} \text { flaxseed })\end{array}$ & $\begin{array}{l}\text { ORAC Value } \\
(\mu \mathrm{mol} \mathrm{TE} / \mathrm{g} \text { flaxseed })\end{array}$ & $\begin{array}{l}\% \mathrm{DPPH}_{\mathrm{dis}} \\
\text { Crude }\end{array}$ & $\begin{array}{l}\% \beta \text {-Carotene } \\
\text { inhibition }\end{array}$ \\
Pure & $10.5 \pm 0.2$ & $38.5 \pm 0.7$ & $53.7 \pm 2.8$ & $68.3 \pm 9.2$ \\
$p$-value & $5.7 \pm 0.1$ & $*$ & $38.2 \pm 1.7$ & $24.9 \pm 1.4$ \\
\hline
\end{tabular}

${ }^{*}$ Significantly different at $\mathrm{P}<0.05$.

** Significantly different at $\mathrm{P}<0.001$.

\subsection{Antioxidant Activity}

\subsubsection{ORAC Assay}

Figure 1 illustrates the fluorescence decay of fluorescein during the ORAC assay. The fluorescence intensity decline is related to the degree of free radical damage. A sample with antioxidant capacity can inhibit the free radical damage resulted in a protection against fluorescence probe destruction in the ORAC assay (Huang, Ou, Hampsch-Woodill, Flanagan, \& Prior, 2002). As expected, the blank sample (phosphate buffer) lacking any antioxidant compounds showed a sharp decrease in fluorescence. Trolox at concentration of $100 \mu \mathrm{M}$ showed a 10 min delay period and after that the decomposition of fluorescein speeded up. The crude flaxseed mucilage had a relatively $10 \mathrm{~min}$ delay period and gradual decrease in fluorescence intensity to the end of test. There was about 5 min delay period for pure flaxseed mucilage was followed by a gradual fluorescence decrease.

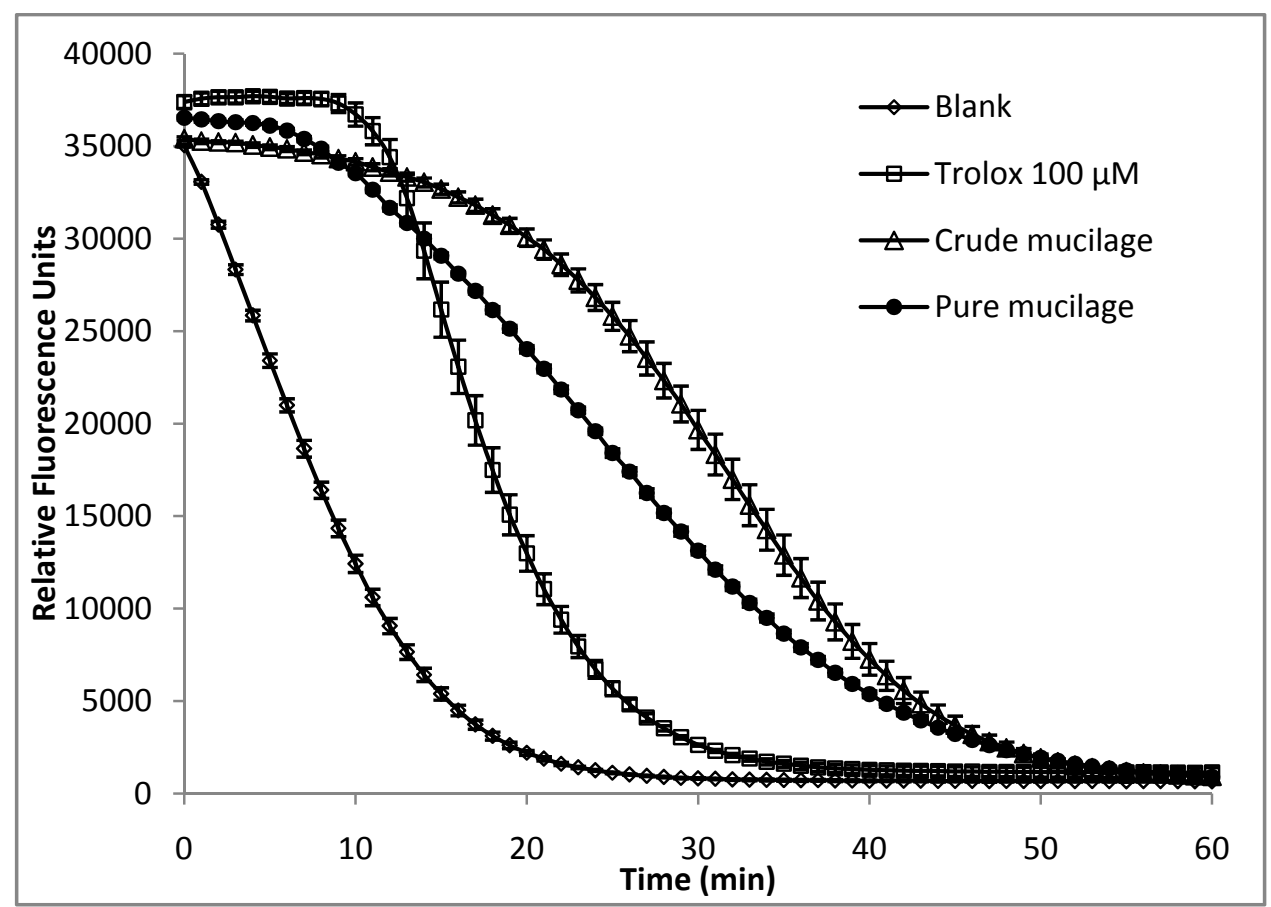

Figure 1. Fluorescence decay curves of fluorescein during the ORAC assay for blank (phosphate buffer), 100 $\mu \mathrm{M}$ troloxsolution, crude, and pure flaxseed mucilage. Error bars on each data point show $\pm \mathrm{SD}$

Final ORAC values were calculated using the Trolox calibration curve and expressed as micromole Trolox equivalents per gram for samples. The crude mucilage had significantly $(\mathrm{P}<0.05)$ higher antioxidant activity compared to the pure mucilage (Table 2). Under similar experimental condition, the crude flaxseed mucilage showed a higher antioxidant activity $(51.2 \mu \mathrm{mol} \mathrm{TE} / \mathrm{g})$ than triticale bran $(33.9 \mu \mathrm{mol} \mathrm{TE} / \mathrm{g}$; Agil \& Hosseinian, 
2012), and the green and red lentil (46.1 and $43.1 \mu \mathrm{mol} \mathrm{TE} / \mathrm{g}$ ), respectively (Agil et al., 2012).

\subsubsection{DPPH Free Radical Scavenging Results}

Figure 2 depicts the kinetic of DPPH free radical scavenging activity of the crude and pure flaxseed mucilage. Although at first $30 \mathrm{~min}$ of reaction crude flaxseed mucilage showed less activity compared to pure mucilage, however after that its reactivity speeded up. After $60 \mathrm{~min}$, crude flaxseed mucilage achieved significantly $(\mathrm{p}<$ $0.05)$ higher discoloration of DPPH radical than pure mucilage $(53.7 \%$ and $38.2 \%$, respectively, Table 2$)$, showing more antioxidant capacity which is in parallel with the TPC results.

Sharma and Bhat (2009) also reported a time dependent for DPPH radical scavenging activity. They reported a rapid radical scavenging reaction of ascorbic acid and propyl gallate with DPPH while the reaction of BHT with DPPH was slow. The flaxseed lignin (SDG and SECO) both have been reported to show strong and concentration dependence free radical scavenging activity against DPPH (Hu, Yuan, \& Kitts, 2007).

\subsection{3 $\beta$-Carotene Assay}

The $\beta$-Carotene assay results (Table 2) showed significant difference $(\mathrm{P}<0.001)$ between crude and pure flaxseed mucilage, with the crude mucilage having higher $\% \beta$-Carotene inhibition $(68.3 \%)$ than the pure mucilage (24.9\%). The $\beta$-carotene bleaching assay is a suitable method to measure the antioxidant activity of the plant extracts since $\beta$-carotene is highly sensitive to linoleic acidoxidation. The delay in $\beta$-carotene discolouration is a measurement of antioxidant activity (Dapkevicius, Venskutonis, Beek, \& Linssen, 1998).

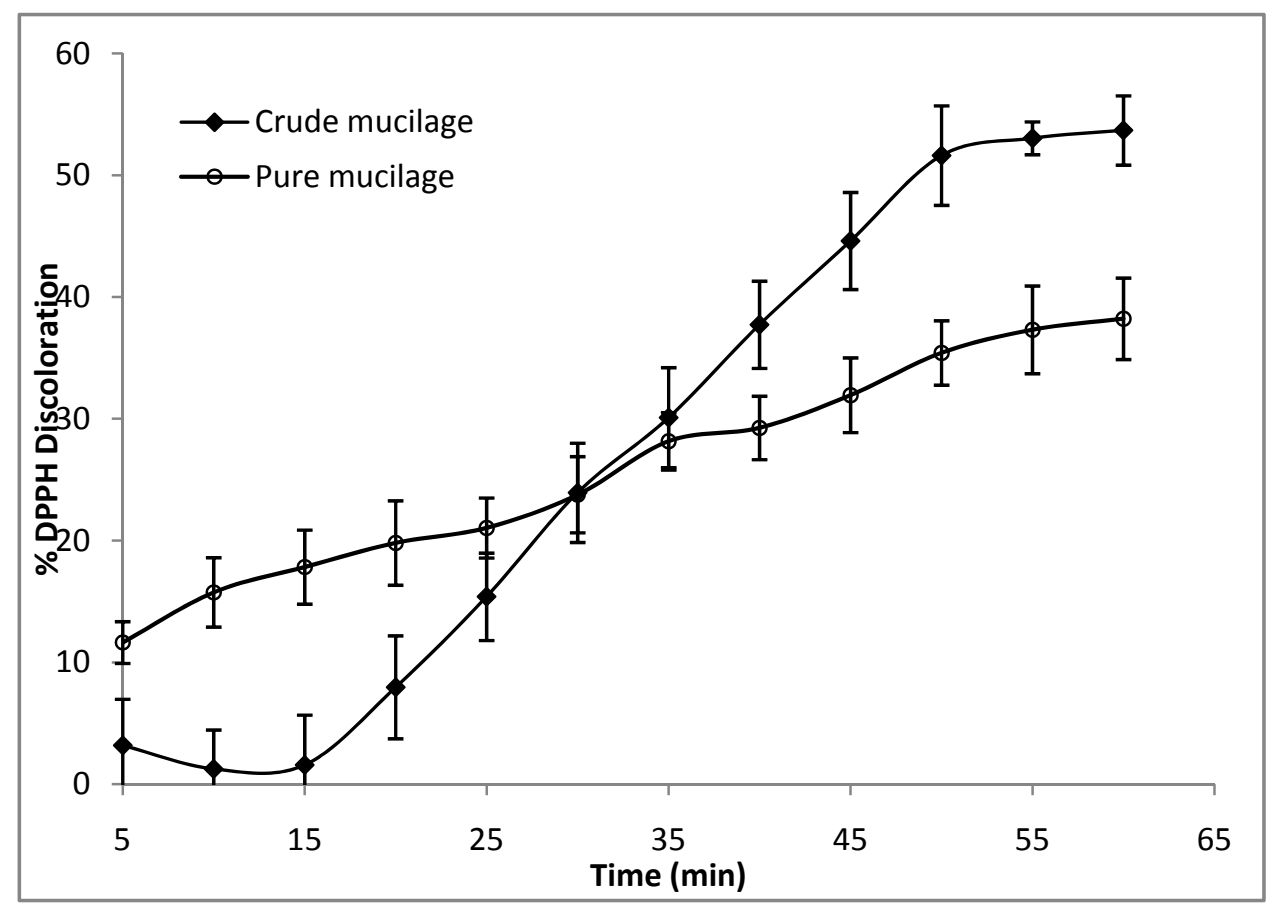

Figure 2. Kinetic of DPPH free radical scavenging activity for the crude and pure flaxseed mucilage. Error bars on each data point show $\pm \mathrm{SD}$

High antioxidant activity of flaxseed mucilage measured in this study could provide additional benefit in kefir along with prebiotic functionality of these natural bioactive compounds. Similar dual functionality has also been suggested for triticale bran and green lentil using yogurt as a food model system (Agil \& Hosseinian, 2012; Agil et al., 2013). However, under similar experimental condition, prebiotic activity of flaxseed mucilage showed a more pronounced effect on bacteria viability; above $9 \mathrm{cfu} / \mathrm{mL}$ total bacteria counts in yogurt drink with flaxseed mucilage compared to 8.2 and $8.3 \mathrm{cfu} / \mathrm{mL}$ for yogurt containing green lentil and triticale bran on day 28 , respectively. Also, as previously mentioned, antioxidant activity of crude flaxseed mucilage was higher than green lentil and much higher than triticale bran measured by a similar ORAC assay. 


\subsection{Probiotic Activity}

\subsubsection{Microbial Analyses}

The evolution of total bacteria $(\log \mathrm{cfu} / \mathrm{mL})$ at days 1, 7, 14, 21 and 28 in kefir samples is shown in Figure 3 ((a), (b), (c), and (d)). On the day 1, the count of bacteria ranged from 6.6 to $7.0 \log \mathrm{cfu} / \mathrm{mL}$ for all the samples, with significantly $(\mathrm{P}<0.001)$ higher values for the treatments supplemented with crude or pure flaxseed mucilage (except for treatments including probiotic 2). All kefir samples showed marked increase in the total bacteria count on the day 7 compared to day 1, indicating a significant growth activity of bacteria. It seems lactic fermentation has been completed by the day 7. This could be explained by slower fermentation of lactic acid bacteria in the presence of yeast in kefir (Collar, 1996). Our results are in agreement with the theory suggesting a symbiotic relationship between yeast and bacteria in kefir in which they can survive and propagate by using each other's bio-products as a nutrient (Viljoen, 2001).The theory suggests that lactic acid bacteria produces galactose which can be digested by yeast which in turn can produce vitamins which boost the growth of the lactic acid bacteria. Also, Xie, Zhou, and Li (2012) demonstrated that the yeast (S. Cerevisiae) enhanced probiotic potential of Lactobacillus paracasei H9 (both isolated from kefir grain), and the two strains showed some positive effects of co-aggregation which can increase the gastrointestinal survivability of the probiotic.
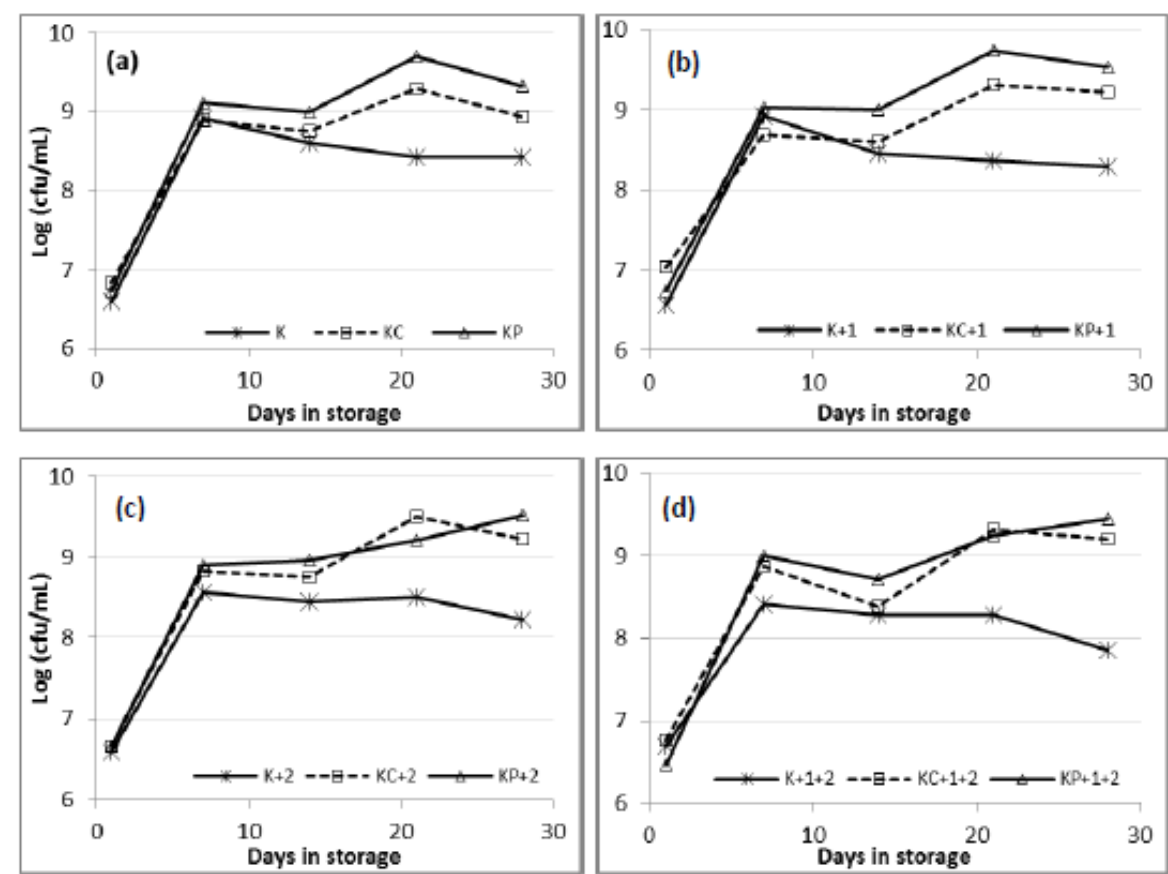

Figure 3. Enumeration of total bacteria in kefir samples; (a) K: kefir, KC: kefir supplemented with crude mucilage, KP: kefir supplemented with pure mucilage; (b), (c), and (d), the same treatments as (a) supplemented with probiotics Lactobacillus acidophilus $(+1)$, Bifidobacterium lactis $(+2)$, and both probiotics $(+1+2)$, respectively, during 28 days cold storage

Overall, after the day 14 , kefir samples supplemented with flaxseed mucilage provided significantly $(\mathrm{P}<0.001)$ higher viability of bacteria in comparison with their respective samples without flaxseed mucilage. These results demonstrated the potential ability of pure mucilage as well as crude flaxseed mucilage in kefir systems with or without probiotics to enhance the microbial survival and growth. The polysaccharides of flaxseed mucilage have been classified in two groups of neutral and acidic fraction which mainly composed of arabinoxylan and rhamonogalacturonan I, respectively (Naran, Chen, \& Carpita, 2008; Warrand et al., 2003). Our findings confirm the results reported by (Fodje et al., 2009) which showed the highest fermentation rate of flaxseed mucilage in comparison to wheat or rye bran, due to higher soluble fibre content in flaxseed mucilage. Kefir samples without probiotics and supplemented with probiotic 1 showed a significantly $(\mathrm{P}<0.001)$ higher bacteria growth in the samples containing pure flaxseed mucilage than crude flaxseed mucilage (Figure 3(a) and (b)). It seems Lactobacillus acidophilus could propagate better in presence of pure flaxseed mucilage compared to crude 
flaxseed mucilage while the same trend was not observed for Bifidobacterium lactisor combined probiotics treatments (Figure 3(c) and (d)). The most pronounced effect of different treatments on the behaviour of probiotics was observed in day 21; the kefir samples supplemented with Lactobacillus acidophilus showed highest microbial counts for pure mucilage treatment while for crude mucilage-added kefir, samples having Bifidobacterium lactis or showed the highest bacterial count and combining both probiotics resulted in no statistically different amount of bacteria growth for pure and crude mucilage. Roberfroid and Slavin (2000) reported that galacto-oligosaccharides are readily fermentable by Bifidobacteria, some strains of bacteroides, lactobacilli, and enterobacteriaceae.

Throughout day 7 to day 28 , total bacteria counts decreased significantly $(\mathrm{P}<0.001)$ in control kefir samples with or without probiotics but lacking flaxseed mucilage, confirming that adding probiotics in dairy products do not guarantee the microbial flora expected from their intake during storage period. Kefir samples supplemented with Bifidobacterium lactis probiotic were more vulnerable to bacteria declining especially after day 21 (Figure3(c) and (d)). The observed decrease in bacteria growth could be due to the decrease in the amount of remaining sugar in milk resulting in fewer nutrients for their growth promotion. Along the same line, a significant decrease $(2 \log \mathrm{cfu} / \mathrm{mL})$ in lactobacilli and Lactococci counts was also reported during 28 days storage of kefir (Irigoyen, Arana, Castiella, Torre, \& Ibáñez, 2005) which also showed the levels of lactococci and lactobacilli strains were inversely proportional to the quantity of kefir grains inoculated, probably because of their sensitivity to the low $\mathrm{pH}$.

A range of 6-8 $\log \mathrm{cfu} / \mathrm{mL}$ is the recommended level for probiotic bacteria which expected to be survived during the cold storage period (Vasiljevic \& Shah, 2008). Our results showed that, by the end of cold storage period, the kefir treatments illustrated total bacteria counts range from 7.85 to $9.53 \log \mathrm{cfu} / \mathrm{mL}$ which confirms the ability of kefir samples to keep the acceptable bacteria levels by the of storage time.

\subsubsection{Total Titratable Acidity (\%TTA) and $\mathrm{pH}$}

Table 3 shows $\mathrm{pH}$ value of kefir samples during the cold storage period at $4{ }^{\circ} \mathrm{C}$. An overall $\mathrm{pH}$ decline of about 0.2 units was observed during cold storage period. On the day 1 , all kefir samples with or without mucilage addition showed a trend of decrease in $\mathrm{pH}$ as probiotic 1,2 and combination of 1 and 2 supplemented to the samples, respectively. This could be as a result of more bacteria activity, causing more acidic media. On the day 7 , most Kefir samples showed significant decrease $(\mathrm{P}<0.001)$ in $\mathrm{pH}$ compared to the day1, except sample $\mathrm{K}+1+2$. As observed in the bacteria growth results, continuing lactic acid fermentation by the day 7 could be resulted in $\mathrm{pH}$ decline. After the day 7, $\mathrm{pH}$ did not show drastic change to the end of cold storage period. After day 21, kefir samples with crude flaxseed mucilage, with or without probiotics, showed lower $\mathrm{pH}$ values compared to their respective treatments supplemented with pure mucilage. Overall, our results demonstrated that kefir samples with or without mucilage while promoting bacteria viability, however, did not cause drastic decrease in the $\mathrm{pH}$ of the media. This is in excellent agreement with findings by Guzel-Seydim, Kok-Tas, Ertekin-Filiz, and Seydim (2011) which reported kefir samples stored in fridge up to period of 21 days showed no change in $\mathrm{pH}$. Changing in $\mathrm{pH}$ during storage time is a big problem for other milk products such as yoghurt. Our results for kefir samples $\mathrm{pH}$ and their variation are well in agreement with the study of Irigoyen et al. (2005) that reported no significant change in $\mathrm{pH}$ of kefir samples during the storage probably due to the yeasts presence. Our findings for $\mathrm{pH}$ during cold storage time can be discussed by the fact that lactic acid bacteria activity decrease in the presence of yeasts (Collar, 1996) resulting in less lactic and acetic acids production. In other hands, dietary fibres such as galactooligosaccharides improve the probiotic growth without significant decrease in $\mathrm{pH}$ (Mei, Carey, Tosh, \& Kostrzynska, 2011).

Table 4 illustrates the TTA values of kefir samples during the cold storage period. Probiotic bacteria produce acids such as butyric, lactic and propionic acid with lactic acid being the most prevalent (Shah, 2000). The trend described for $\mathrm{pH}$ comparisons on the day 1 was confirmed by the trend of TTA, showing an increase in acidity of kefir samples when probiotic 1, 2, and both of them were incorporated, respectively. Lactic fermentation seems to continue by the day 7 resulting in more TTA. From the day 14 by the end of cold storage period, kefir samples without flaxseed mucilage showed a significantly $(\mathrm{P}<0.001)$ decrease in TTA, while the kefir samples supplemented with crude and especially pure mucilage showed an increase in TTA. In agreement with our findings, Irigoyen et al. (2005) found that during refrigerated storage of kefir lactic acid bacteria will begin to decrease, while the numbers of yeasts and acetic acid bacteria will remain fairly consistent which can resulted in more acidic media. Overall at the end of cold storage period, the kefir samples containing pure flaxseed mucilage produce more acidic compounds in comparison with kefir samples without mucilage or with crude mucilage confirming that pure mucilage favors the growth of lactic acid bacterial. Although $\mathrm{pH}$ value did not showed drastic change, it seems probiotic activity of pure mucilage enhance producing short-chain fatty acids which 
preferably were in disassociated form, causing higher acidity (TTA) but not necessarily lower pH value.

Table 3. Evaluation of $\mathrm{pH}$ of different kefir formulations during 28 days of storage at $4{ }^{\circ} \mathrm{C}$

\begin{tabular}{llllll}
\hline Treatment & $\mathbf{p H}^{\ddagger}$ & & & \\
\cline { 2 - 6 } & Day 1 & Day 7 & Day 14 & Day 21 & Day 28 \\
\hline $\mathrm{K}$ & $4.37 \pm 0.01$ & $4.28 \pm 0.01$ & $4.24 \pm 0.01$ & $4.21 \pm 0.01$ & $4.20 \pm 0.01$ \\
$\mathrm{~K}+1$ & $4.32 \pm 0.01$ & $4.26 \pm 0.01$ & $4.23 \pm 0.01$ & $4.21 \pm 0.00$ & $4.19 \pm 0.01$ \\
$\mathrm{~K}+2$ & $4.27 \pm 0.01$ & $4.24 \pm 0.00$ & $4.22 \pm 0.01$ & $4.20 \pm 0.01$ & $4.18 \pm 0.01$ \\
$\mathrm{~K}+1+2$ & $4.23 \pm 0.01$ & $4.23 \pm 0.01$ & $4.20 \pm 0.01$ & $4.20 \pm 0.00$ & $4.18 \pm 0.01$ \\
\hdashline $\mathrm{KC}$ & $4.34 \pm 0.01$ & $4.25 \pm 0.01$ & $4.23 \pm 0.01$ & $4.19 \pm 0.01$ & $4.18 \pm 0.01$ \\
$\mathrm{KC}+1$ & $4.26 \pm 0.01$ & $4.22 \pm 0.01$ & $4.22 \pm 0.01$ & $4.18 \pm 0.01$ & $4.18 \pm 0.00$ \\
$\mathrm{KC}+2$ & $4.23 \pm 0.01$ & $4.20 \pm 0.01$ & $4.21 \pm 0.00$ & $4.19 \pm 0.01$ & $4.18 \pm 0.01$ \\
$\mathrm{KC}+1+2$ & $4.20 \pm 0.00$ & $4.19 \pm 0.01$ & $4.20 \pm 0.00$ & $4.18 \pm 0.01$ & $4.17 \pm 0.01$ \\
$-\mathrm{KP}$ & $4.33 \pm 0.01$ & $4.26 \pm 0.01$ & $4.24 \pm 0.01$ & $4.24 \pm 0.01$ & $4.22 \pm 0.01$ \\
$\mathrm{KP}+1$ & $4.30 \pm 0.01$ & $4.25 \pm 0.00$ & $4.23 \pm 0.01$ & $4.23 \pm 0.01$ & $4.21 \pm 0.01$ \\
$\mathrm{KP}+2$ & $4.26 \pm 0.01$ & $4.24 \pm 0.01$ & $4.23 \pm 0.01$ & $4.23 \pm 0.01$ & $4.22 \pm 0.01$ \\
$\mathrm{KP}+1+2$ & $4.22 \pm 0.011$ & $4.22 \pm 0.01$ & $4.22 \pm 0.01$ & $4.23 \pm 0.01$ & $4.22 \pm 0.01$ \\
\hline
\end{tabular}

* Kefir samples coding are described in Table 1.

${ }^{\neq}$Values are means $(\mathrm{n}=3) \pm \mathrm{SD}$.

Table 4. Evaluation of total titratable acid (TTA)of different kefir formulations during 28 days storage at $4{ }^{\circ} \mathrm{C}$

\begin{tabular}{llllll}
\hline Treatment $^{*}$ & \multicolumn{5}{l}{ TTA (\%) } \\
\cline { 2 - 6 } & Day 1 & Day 7 & Day 14 & Day 21 & Day 28 \\
\hline $\mathrm{K}$ & $0.55 \pm 0.01$ & $0.57 \pm 0.03$ & $0.63 \pm 0.02$ & $0.60 \pm 0.03$ & $0.56 \pm 0.02$ \\
$\mathrm{~K}+1$ & $0.57 \pm 0.03$ & $0.60 \pm 0.03$ & $0.62 \pm 0.03$ & $0.59 \pm 0.03$ & $0.56 \pm 0.02$ \\
$\mathrm{~K}+2$ & $0.60 \pm 0.03$ & $0.65 \pm 0.02$ & $0.64 \pm 0.02$ & $0.60 \pm 0.02$ & $0.57 \pm 0.02$ \\
$\mathrm{~K}+1+2$ & $0.62 \pm 0.03$ & $0.68 \pm 0.02$ & $0.65 \pm 0.02$ & $0.60 \pm 0.02$ & $0.59 \pm 0.01$ \\
\hline $\mathrm{KC}$ & $0.59 \pm 0.03$ & $0.62 \pm 0.01$ & $0.63 \pm 0.02$ & $0.62 \pm 0.02$ & $0.63 \pm 0.02$ \\
$\mathrm{KC}+1$ & $0.65 \pm 0.02$ & $0.67 \pm 0.02$ & $0.68 \pm 0.03$ & $0.68 \pm 0.03$ & $0.70 \pm 0.01$ \\
$\mathrm{KC}+2$ & $0.67 \pm 0.02$ & $0.70 \pm 0.01$ & $0.70 \pm 0.02$ & $0.70 \pm 0.02$ & $0.72 \pm 0.01$ \\
$\mathrm{KC}+1+2$ & $0.69 \pm 0.01$ & $0.71 \pm 0.02$ & $0.70 \pm 0.01$ & $0.71 \pm 0.02$ & $0.72 \pm 0.02$ \\
$-\mathrm{KP}$ & $0.65 \pm 0.02$ & $0.71 \pm 0.02$ & $0.73 \pm 0.02$ & $0.76 \pm 0.01$ & $0.77 \pm 0.01$ \\
$\mathrm{KP}+1$ & $0.66 \pm 0.02$ & $0.71 \pm 0.01$ & $0.74 \pm 0.02$ & $0.76 \pm 0.02$ & $0.77 \pm 0.01$ \\
$\mathrm{KP}+2$ & $0.70 \pm 0.02$ & $0.72 \pm 0.01$ & $0.75 \pm 0.01$ & $0.77 \pm 0.02$ & $0.78 \pm 0.01$ \\
$\mathrm{KP}+1+2$ & $0.70 \pm 0.02$ & $0.72 \pm 0.01$ & $0.75 \pm 0.01$ & $0.78 \pm 0.01$ & $0.78 \pm 0.02$ \\
\hline
\end{tabular}

*Kefir samples coding are described in Table 1.

${ }^{\neq}$Values are means $(\mathrm{n}=3) \pm \mathrm{SD}$.

\section{Conclusion}

This study was conducted for the first time to investigate the potential of flaxseed mucilage to boost the bacterial growth in kefir system. The results demonstrated that flaxseed mucilage acts as a good source of prebiotic, enhancing lactic acid bacteria growthin kefir model. Pure flaxseed mucilage showed better prebiotic 
functionality compared to the crude flaxseed mucilage without causing a drastic decline in $\mathrm{pH}$. High antioxidant activity of flaxseed mucilage confirmed additional beneficiary of incorporation of these natural bioactive compounds in kefir system.Using microwave extraction technique for flaxseed mucilage resulted in higher TPC value which reflects the merit of this green and environmental friendlytechnique as a promising free-solvent method to extract plant bioactives. Considering processing time and expense for purification crude flaxseed mucilage, our results demonstrated that using crude flaxseed mucilage as a source of prebioticcould still provide acceptable bacterial viability as well as high antioxidant protection. Future studies including investigation of sensory and rheologicalcharacteristics of kefir samples containing flaxseed mucilage would be useful to know impacts on kefir sensorial and textural properties. Also, in vivo animal and clinical study are necessary to determine health-related properties of kefir supplemented with flaxseed mucilage.

\section{Acknowledgement}

This work was supported by the Natural Sciences and Engineering Research Council of Canada (NSERC-Engage) and the Carleton University Start-up funds. Authors thank to Susanna Fang for her assistance during this study.

\section{References}

Agil, R., \& Hosseinian, F. (2012). Dual functionality of triticale as a novel dietary source of prebiotics with antioxidant activity in fermented dairy products. Plant Foods for Human Nutrition, 67, 88-93. http://dx.doi.org/10.1007/s11130-012-0276-2

Agil, R., Gaget, A., Gliwa, J., Avis, T. J., Willmore, B., \& Hosseinian, F. (2013). Lentils enhance probiotic growth in yogurt and provide added benefit of antioxidant protection. LWT - Food Science and Technology, 50, 45-49. http://dx.doi.org/10.1016/j.lwt.2012.07.032

AidiWannes, W., Mhamdi, B., Sriti, J., Ben Jemia, M., Ouchikh, O., Hamdaoui, G., ... Marzouk, B. (2010). Antioxidant activities of the essential oils and methanol extracts from myrtle (Myrtuscommunis var. italica L.) leaf, stem, and flower. Food and Chemical Toxicology, 48, 1362-1370. http://dx.doi.org/10.1016/j.fct.2010.03.002

Beejmohun, V., Fliniaux, O., Grand, E., Lamblin, F., Bensaddek, L., Christen, P., \& Mesnard, F. (2007). Microwave assisted extraction of the main phenolic compounds in flaxseed. Phytochemical Analysis, 18, 275-282. http://dx.doi.org/10.1002/pca.973

Bloedon, L. T., \& Szapary, P. O. (2004). Flaxseed and cardiovascular risk. Nutrition Reviews, 62, 18-27. http://dx.doi.org/10.1111/j.1753-4887.2004.tb00002.x

Chiremba, C., Rooney, L. W., \& Beta, T. (2012). Microwave-assisted extraction of bound phenolic acids in bran and flour fractions from sorghum and maize cultivars varying in hardness. Journal of Agricultural and Food Chemistry, 60, 4735-4742. http://dx.doi.org/10.1021/jf300279t

Collar, C. (1996). Biochemical and technological assessment of the metabolism of pure and mixed cultures of yeast and lactic acid bacteria in breadmaking applications. Food Science and Technology International, 2, 349-367. http://dx.doi.org/10.1177/108201329600200601

Cui, W., \& Mazza, G. (1996). Physicochemical characteristics of flaxseed gum. Food Research International, 29, 397-402. http://dx.doi.org/10.1016/0963-9969(96)00005-1

Dapkevicius, A., Venskutonis, R., Beek, T. A. V., \& Linssen, J. P. H. (1998). Antioxidant activity of extracts obtained by different isolation procedures from some aromatic herbs grown in Lithuania. Journal of the $\begin{array}{lllll}\text { Science } & \text { Food agriculture, } & \text { 140 } & \text { and }\end{array}$ http://dx.doi.org/10.1002/(SICI)1097-0010(199805)77:1<140::AID-JSFA18>3.3.CO;2-B

Espirito Santo, A. P., Silva, R. C., Soares, F. A. S. M., Anjos, D., Gioielli, L. A., \& Oliveira, M. N. (2010). Açai pulp addition improves fatty acid profile and probiotic viability in yoghurt. International Dairy Journal, 20, 415-422. http://dx.doi.org/10.1016/j.idairyj.2010.01.002

Fodje, A. M. L., Chang, P. R., \& Leterme, P. (2009). In vitro bile acid binding and short chain fatty acid profile of flax fiber and ethanol co-products. Journal of Medicinal Food, 12, 1065-1073. http://dx.doi.org/10.1089/jmf.2008.0242

Gibson, G. R., Probert, H. M., Loo, J. V., Rastall, R. A., \& Roberfroid, M. B. (2004). Dietary modulation of the human colonic microbiota: updating the concept of prebiotics. Nutrition Research Review, 17, 259-275. http://dx.doi.org/10.1079/NRR200479 
Gutiérrez, C., Rubilar, M., Jara, C., Verdugo, M., Sineiro, J., \& Shene, C. (2010). Flaxseed and flaxseed cake as a source of compounds for food industry. Journal of Soil science and Plant Nutrition, 10, 454-463.

Guzel-Seydim, Z., Kok-Tas, T., Ertekin-Filiz, B., \& Seydim, A. C. (2011). Effect of different growth conditions on biomass increase in kefir grains. Journal of Dairy Science, 94, 1239-1242. http://dx.doi.org/10.3168/jds.2010-3349

Hertzler, S. R., \& Clancy, S. M. (2003). Kefir improves lactose digestion and tolerance in adults with lactose maldigestion. Journal of the American Dietetic Association, 103, 582-587. http://dx.doi.org/10.1053/jada.2003.50111

Hijova, E., Chmelarova, A., \& Bomba, A. (2011). Improved efficacy of prebiotic by flaxseed oil and horse chestnut in experimental colon cancer. Bratislava Medical Journal, 112, 161-164.

Hosono, A., Tanabe, T., \& Otani, H. (1990). Binding properties of lactic acid bacteria isolated from kefir milk with mutagenic amino acid pyrolyzates. Milchwissenschaft, 45, 647-651.

Hosseinian, F. S., \& Mazza, G. (2009). Triticale bran and straw: Potential new sources of phenolic acids, proanthocyanidins, and lignans. Functional Foods, 1, 57-64. http://dx.doi.org/10.1016/j.jff.2008.09.009

Hu, C., Yuan, Y. V., \& Kitts, D. D. (2007). Antioxidant activities of the flaxseed lignan secoisolariciresinol diglucoside, its aglycone secoisolariciresinol and the mammalian lignans enterodiol and enterolactone in vitro. Food and Chemical Toxicology, 45, 2219-2227. http://dx.doi.org/10.1016/j.fct.2007.05.017

Huang, D., Ou, B., Hampsch-Woodill, M., Flanagan, J. A., \& Prior, R. L. (2002). High-throughput assay of oxygen radical absorbance capacity (ORAC) using a multichannel liquid handling system coupled with a microplate fluorescence reader in 96-well format. Journal of Agricultural and Food Chemistry, 50, 4437-4444. http://dx.doi.org/10.1021/jf0201529

Irigoyen, A., Arana, I., Castiella, M., Torre, P., \& Ibáñez, F. C. (2005). Microbiological, physicochemical, and sensory characteristics of kefir during storage. Food Chemistry, 90, 613-620. http://dx.doi.org/10.1016/j.foodchem.2004.04.021

Kök-Tas, T., Ekinci, F. Y., \& Güzel-Seydim Z. B. (2012). Identification of microbial flora in kefir grains produced in Turkey using PCR. International Journal of Dairy Technology, 65, 126-131. http://dx.doi.org/10.1111/j.1471-0307.2011.00733.x

Kozlowska, H., Zadernowski, R., \& Sosulski, F. W. (1983). Phenolic acids in oilseed flours. Nahrung, 27, 449-453. http://dx.doi.org/10.1002/food.19830270517

Li, W., Hydamaka, A. W., Lowry, L., \& Beta, T. (2009). Comparison of antioxidant capacity and phenolic compounds of berries, chokecherry and seabuckthorn. Central European Journal of Biology, 4, 499-506. http://dx.doi.org/10.2478/s11535-009-0041-1

MacRae, W. D., \& Towers, G. H. N. (1984). Biological activities of lignans. Phytochemistry, 23, 1207-1220. http://dx.doi.org/10.1016/S0031-9422(00)80428-8

Mazur, W., Fotsis, T., Wähälä, K., Ojala, S., Salakka, A., \& Adlercreutz, H. (1996). Isotope dilution gas chromatographic-mass spectrometric method for the determination of isoflavonoids, coumestrol, and lignans in food samples. Analytical Biochemistry, 233, 169-180. http://dx.doi.org/10.1006/abio.1996.0025

Mei, G. Y., Carey, C. M., Tosh, S., \& Kostrzynska, M. (2011). Utilization of different types of dietary fibres by potential probiotics. Canadian Journal of Microbiology, 57, 857-865. http://dx.doi.org/10.1139/w11-077

Miguel, M. G. C. P., Cardoso, P. G., Lago, L. A., \& Schwan, R. F. (2010). Diversity of bacteria present in milk kefir grains using culture-dependent and culture-independent methods. Food Research International, 43, 1523-1528. http://dx.doi.org/10.1016/j.foodres.2010.04.031

Naran, R., Chen, G. B., \& Carpita, N. C. (2008). Novel rhamnogalacturonan I and arabinoxylan polysaccharides of flax seed mucilage. Plant Physiology, 148, 132-141. http://dx.doi.org/10.1104/pp.108.123513

Nemes, S. M., \& Orsat, V. (2011). Microwave-Assisted Extraction of Secoisolariciresinol Diglucoside-Method $\begin{array}{lllll}\text { Development. Food and Bioprocess Technology, } & \text { 4, }\end{array}$ http://dx.doi.org/10.1007/s11947-009-0213-z

Oomah, B. D., Kenaschuck, E. O., \& Mazza, G. (1995). Phenolic acids in flaxseed. Journal of Agricultural and Food Chemistry, 43, 2016-2019. http://dx.doi.org/10.1021/jf00056a011

Roberfroid, M., \& Slavin, J. (2000). Nondigestible Oligosaccharides. Critical Reviews in Food Science and 
Nutrition, 40, 461-480. http://dx.doi.org/10.1080/10408690091189239

Shah, N. P. (2000). Probiotic bacteria: selective enumeration and survival in Dairy food. Journal of Dairy Science, 83, 894-907. http://dx.doi.org/10.3168/jds.S0022-0302(00)74953-8

Sharma, O. P., \& Bhat, T. K. (2009). DPPH antioxidant assay revisited. Food Chemistry, 113, 1202-1205. http://dx.doi.org/10.1016/j.foodchem.2008.08.008

Simova, E., Beshkova, D., Angelov, A., Hristozova, Ts., Frengova, G., \& Spasov, Z. (2002). Lactic acid bacteria and yeasts in kefir grains and kefir made from them. Journal of Industrial Microbiology \& Biotechnology, 28, 1-6. http://dx.doi.org/10.1038/sj.jim.7000186

Singh, R. S., \& Singh, R. P. (2010). Production of fructooligosaccharides from inulin by endoinulinases and their prebiotic potential. Food Technology and Biotechnology, 48, 435-450.

Thompson, L. U., Robb, P., Serraino, M., \& Cheung, F. (1991). Mammalian lignan production from various foods. Nutrition and Cancer, 16, 43-52. http://dx.doi.org/10.1080/01635589109514139

Torres, D. P. M., Goncalves, M. P. F., Teixeira, J. A., \& Rodrigues, L. R. (2010). Galacto-Oligosaccharides: Production, Properties, Applications, and Significance as Prebiotics. Comprehensive Reviews in Food Science and Food Safety, 9, 438- 454. http://dx.doi.org/10.1111/j.1541-4337.2010.00119.x

Vasiljevic, T., \& Shah, N. P. (2008). Probiotics - from Metchnikoff to bioactives. International Dairy Journal, 18, 714-728. http://dx.doi.org/10.1016/j.idairyj.2008.03.004

Viljoen, B. C. (2001). The interaction between yeasts and bacteria in dairy environments. International Journal of Food Microbiology, 69, 37-44. http://dx.doi.org/10.1016/S0168-1605(01)00570-0

Vinderola, G., Perdigon, G., Duarte, J., Farnworth, E., \& Matar, C. (2006). Effects ofthe oral administration of the products derived from milk fermentation by kefir microflora on immune stimulation. Journal of Dairy Research, 73, 472-479. http://dx.doi.org/10.1017/S002202990600197X

Warrand, J., Michaud, P., Picton, L., Muller, G., Courtois, B., Ralainirina, R., \& Courtois, J. (2003). Large-scale purification of water-soluble polysaccharides from flaxseed mucilage, and isolation of a new anionic polymer. Chromatographia, 58, 331-335.

Xie, N., Zhou, T., \& Li, B. (2012). Kefir yeasts enhance probiotic potentials of Lactobacillus paracasei H9: The positive effects of coaggregation between the two strains. Food Research International, 45, 394-401. http://dx.doi.org/10.1016/j.foodres.2011.10.045

\section{Copyrights}

Copyright for this article is retained by the author(s), with first publication rights granted to the journal.

This is an open-access article distributed under the terms and conditions of the Creative Commons Attribution license (http://creativecommons.org/licenses/by/3.0/). 